\title{
Derivative Hedging and Insurer Solvency: Evidence from Taiwan
}

\author{
Yung-Ming Shiu \\ Department of Business Administration, National Cheng Kung University, 1, University Road, Tainan 701, \\ Taiwan. \\ E-mail: yungming@mail.ncku.edu.tw
}

Using company-level panel data (2001-2003), this paper empirically examines whether Taiwanese insurers' use of derivatives for hedging purposes is significantly related to their solvency (as measured by solvency ratio). Contrary to the public's perception that firms with derivative programmes have a higher level of solvency if derivatives are employed for hedging purposes, our results indicate that life insurers' derivative hedging generally is not associated with solvency, while non-life insurers using derivative hedging have a lower level of solvency.

The Geneva Papers (2010) 35, 469-483. doi:10.1057/gpp.2010.13

Keywords: derivative use; insurer solvency; hedging

\section{Introduction}

According to Modigliani and Miller's propositions, derivative hedging should be irrelevant in a frictionless world with full information and complete markets. In the real world, however, imperfections exist in capital markets and Modigliani and Miller's propositions do not completely hold. Some previous studies suggest that hedging creates value for firms. ${ }^{1,2}$ It is the public's perception that firms which have derivative programmes for hedging purposes are expected to be less likely to go bankrupt than those which do not. In fact, derivatives could be related to either increased solvency or insolvency risk. This paper aims to examine whether there is any relation between insurer solvency and derivative use/the extent of use.

Wide use of derivative securities in recent decade has generated several studies concerning the relation between the use of derivatives and firm risk. The empirical evidence is inconclusive. For instance, Koski and Pontiff ${ }^{3}$ and Hentschel and Kothari ${ }^{4}$ do not find a relation between derivative use and corporate risk, while Tufano ${ }^{5}$ and Guay $^{6}$ document a positive relation between derivative use and risk reduction. As far

\footnotetext{
${ }^{1}$ Allayannis and Weston (2001).

2 Carter et al. (2006).

${ }^{3}$ Koski and Pontiff (1999).

${ }^{4}$ Hentschel and Kothari (2001).

5 Tufano (1996).

${ }^{6}$ Guay (1999).
} 
470

as the authors understand, there is little, if any, research investigating the relationship between derivative hedging and insolvency risk in the context of insurance.

Derivative markets were originally introduced to eliminate risk for commodities. According to the EU Insurance Directive, however, derivatives are used by insurers to cover technical provisions where they were affected for the purposes of efficient portfolio management or risk reduction, and thus to increase insurer solvency. As described in the United Kingdom Prudential Source Book for Insurers, ${ }^{7}$ derivatives are for efficient portfolio management purposes if they can generate additional capital/income, or reduce tax/investment cost, while derivatives are for risk reduction purposes if they can reduce risk. As such, derivatives in insurance can be used for hedging or nonhedging purposes.

As discussed later in this section, the problem of endogeneity may exist in the analysis. Jin and Jorion ${ }^{8}$ propose three criteria for selecting an ideal sample to examine the issue on hedging premium. First, the sample is obtained from a single industry. Second, financial exposure is important for firms in the sample. Third, these firms have a huge variety of hedging ratios. In this analysis, our sample is limited to insurance firms which are exposed to market risks to a great extent and have diverse hedging programmes. Our sample largely satisfies the criteria proposed by Jin and Jorion. ${ }^{8} \mathrm{We}$ adopt a single industry setting in which risk exposures are likely to be similar across firms to test the relation between derivative hedging and insurer solvency. ${ }^{9}$

Under the Taiwanese "Guidance Note on Derivative Transactions by Insurers" issued by the Financial Supervisory Commission, all authorised insurers carrying on business in Taiwan can only employ derivatives to hedge risks rather than speculate on market price movements. The aim of allowing insurers to engage in derivative hedging is to enable insurers to alleviate the impact of risks on its financial health and thus to increase solvency. The Taiwanese insurance regulators fear that derivatives might be employed for speculative purposes and that derivative use, if not properly controlled, could increase, rather than reduce risk. We examine whether insurer insolvency risk decreases with the use of derivatives. If the insurer uses derivatives for hedging purposes, as required by the regulator, the insolvency risk should be reduced and, thus, its solvency improved. Conversely, if derivatives are used for income enhancement, the risk might be increased and the solvency reduced.

Table 1 presents the number of insurers using derivatives and the extent of their use by industry from 2001 to 2003. During this period, the number of derivative users increases in proportion to the derivatives they held. As documented in Cummins et al. ${ }^{10}$ for the United States insurance market, we find that derivative use in Taiwan's non-life insurance industry is relatively low and that derivative activity is limited almost exclusively to the life sector. ${ }^{11}$ In our analysis, insurers are

${ }^{7}$ Financial Services Authority (2008).

${ }^{8}$ Jin and Jorion (2006).

${ }^{9}$ The single-industry approach has recently been used in assessing the effect of hedging on firm value. See Jin and Jorion (2006) and Carter et al. (2006).

${ }^{10}$ Cummins et al. (1997).

${ }^{11}$ Compared with banks, insurance and reinsurance firms engage less in the derivative markets (Kupiec and Nickerson, 2005). 
Table 1 Number of derivative users and the extent of derivative use by industry

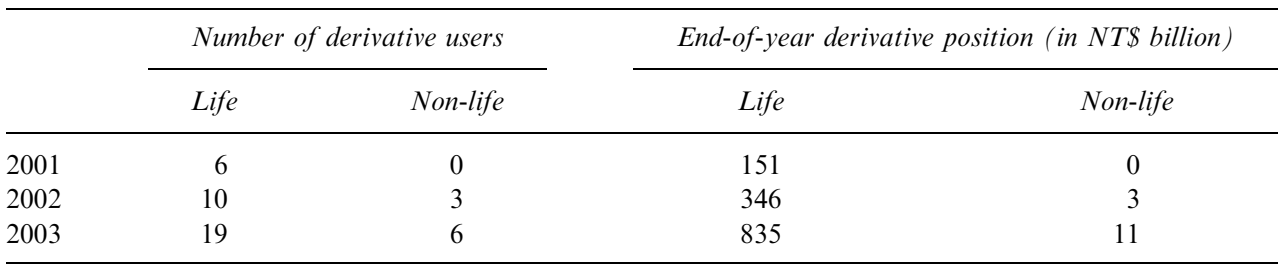

Note: US\$1 is approximately equal to NT\$ 32.5 as of June 2009.

Table 2 Type, number and extent of derivative use

\begin{tabular}{|c|c|c|c|c|c|c|c|c|c|c|c|c|}
\hline \multirow[t]{3}{*}{ Contract type } & \multicolumn{4}{|c|}{2001} & \multicolumn{4}{|c|}{2002} & \multicolumn{4}{|c|}{2003} \\
\hline & \multicolumn{2}{|c|}{$\begin{array}{l}\text { Number } \\
\text { of users }\end{array}$} & \multicolumn{2}{|c|}{$\begin{array}{l}\text { End-of-year } \\
\text { position (in } \\
\text { NT\$ billion) }\end{array}$} & \multicolumn{2}{|c|}{$\begin{array}{l}\text { Number } \\
\text { of users }\end{array}$} & \multicolumn{2}{|c|}{$\begin{array}{l}\text { End-of-year } \\
\text { position (in } \\
\text { NT\$ billion) }\end{array}$} & \multicolumn{2}{|c|}{$\begin{array}{l}\text { Number } \\
\text { of users }\end{array}$} & \multicolumn{2}{|c|}{$\begin{array}{l}\text { End-of-year } \\
\text { position (in } \\
\text { NT\$ billion) }\end{array}$} \\
\hline & Life & Non-life & Life & Non-life & Life & Non-life & Life & Non-life & Life & Non-life & Life & Non-life \\
\hline Currency futures & 1 & 0 & 61 & 0 & 1 & 0 & 75 & 0 & 0 & 0 & 0 & 0 \\
\hline Currency forwards & 4 & 0 & 64 & 0 & 8 & 3 & 167 & 3 & 16 & 6 & 402 & 11 \\
\hline Currency swaps & 1 & 0 & 25 & 0 & 0 & 0 & 0 & 0 & 2 & 0 & 36 & 0 \\
\hline Interest rate swaps & 0 & 0 & 0 & 0 & 1 & 0 & 75 & 0 & 3 & 0 & 330 & 0 \\
\hline Cross currency swaps & 2 & 0 & 1 & 0 & 2 & 0 & 29 & 0 & 3 & 0 & 53 & 0 \\
\hline Currency options & 0 & 0 & 0 & 0 & 0 & 0 & 0 & 0 & 1 & 0 & 10 & 0 \\
\hline Structured notes & 0 & 0 & 0 & 0 & 0 & 0 & 0 & 0 & 2 & 0 & 4 & 0 \\
\hline
\end{tabular}

Note: US\$1 is approximately equal to NT\$ 32.5 as of June 2009.

regarded as a derivative user if they report a non-zero derivative holding at the end of the year. The actual number of derivative users and notional amount of derivatives are expected to be larger than end-of-year number of derivative users and holdings because some positions are opened and closed out during the same calendar year.

Table 2 shows summary information on the types of derivatives used by Taiwanese insurers, the number of insurers using each type of contract and extent to which these types are used during the 2001-2003 period. The most striking finding to emerge from this table is that currency forwards are the only type of derivative contract used by the non-life sector. Moreover, currency forwards are the most popular type of contract in the life sector in terms of number of users and positions held. According to these users' financial statements, currency forwards are utilised to hedge currency risk arising from foreign investments or other operations. Interest rate swaps also account for significant end-of-year volume in the life sector.

Surprisingly, little is known about the linkage between derivative hedging and firm solvency in insurance. This paper seeks to address this gap in the literature by investigating the association between insurer solvency and the use of derivatives for hedging purposes. 
Prior literature on risk management suggests that corporate hedging is aimed at achieving shareholder value maximisation. ${ }^{12,13,5}$ Using off-balance-sheet instruments for hedging reduces insolvency risk and volatility of firm value, and accordingly increases the expected utility of shareholders. On the other hand, greater insolvency risk could motivate more hedging activities with derivatives. Thus, we cannot rule out the possibility that both risk and derivative utilisation might be endogenously or simultaneously determined by certain corporate characteristics. If there exists endogeneity in regressions, our coefficient estimates from the ordinary least squares (OLS) regression would be inconsistent. ${ }^{14}$ As described previously, Jin and Jorion ${ }^{8}$ argue that selecting firms within the same industry is instrumental in alleviating the endogeneity problem. In our analysis, the sample is limited to insurance firms. To further and formally address this problem, we test for endogeneity using the Hausman test devised by $\mathrm{Wu}^{15}$ to identify whether two-stage least squares could be applied to improve consistency in the estimation process. We carry this out before examining the effect of derivative hedging on insolvency risk. In the empirical analysis, we use the solvency ratio to measure insolvency risk. The higher the solvency ratio, the lower the insolvency risk. The findings suggest that derivative use does not seem to affect solvency for the life insurance industry. This implies that derivative use does not decrease or increase life insurer solvency. However, it appears that non-life insurers using derivative hedging have a lower level of solvency.

The remainder of the paper is organised as follows. In the following section, we discuss the related literature. Next, we describe the sample, variables and methodology employed in this study. In the penultimate section, we present the empirical results. The last section concludes and provides some policy implications.

\section{Related literature}

Corporate hedging studies can be broadly classified into two categories. The first is to identify the determinants of decisions on derivative use. The decisions include whether to participate in the derivative markets and the extent to which derivatives are used. Determinants studies ${ }^{16,17,18,19}$ generally base their hypotheses on the shareholder value maximisation argument and the managerial incentives theory. These studies find that several firm-specific factors such as size, growth option and liquidity are potentially related to participation and extent decisions.

\footnotetext{
${ }^{12}$ Smith and Stulz (1985).

${ }^{13}$ Froot et al. (1993).

14 Maddala (2001).

${ }^{15} \mathrm{Wu}$ (1973).

${ }^{16}$ Nance et al. (1993).

${ }^{17}$ Colquitt and Hoyt (1997).

${ }^{18}$ Hardwick and Adams (1999).

${ }^{19}$ Cummins et al. (2001).
} 
Another strand of research is to examine the effect of derivative use on risk, ${ }^{4,6,20}$ firm value $e^{1,2,8}$ or asymmetric information. ${ }^{21}$ Previous studies show mixed results concerning the linkage between derivative usage on firm risk. Analysing a sample of 679 domestic equity mutual funds, Koski and Pontiff ${ }^{3}$ find no differences in risk between derivative users and nonusers. Hentschel and Kothari ${ }^{4}$ find that the riskiness of a firm is not associated with its derivative use. Bali et al. ${ }^{22}$ use the data on non-financial firms from 1995 to 2001 to examine the relation between interest rate, currency and commodity derivatives and their corresponding risk exposures. In their research, little evidence is found to support the view that derivative use reduces the impact of price movements on firms.

Conversely, it is argued that managers can use hedging to decrease insurer insolvency risk and increase solvency. Guay ${ }^{6}$ documents that entity risk declines following derivative use. Using a sample of 99 bank holding companies, Venkatachalam ${ }^{23}$ shows that derivative contracts are employed by these banks to reduce risk. Sinkey and Carter $^{24}$ find that banks with a higher probability of bankruptcy have a propensity to employ derivatives to hedge. Adkins et $a .^{25}$ find that the higher level of currency risk a bank faces, the more currency derivatives it uses for hedging purposes. This implies that a negative relation exists between currency derivative use and bank risk. Allayannis and Ofek (2001) find empirical support for financial firms' use of foreign currency derivatives for hedging purposes. Yang et $a l^{20}$ argue that capital market participants generally perceive that banks use derivatives to hedge risk. Thus, if firms mainly use derivatives to hedge these movements, then we would expect that derivative use should reduce risk exposures. In sum, prior research of this strand is limited to the management of capital market risk for financial and non-financial firms. It is unclear whether the hedging premium exists for insolvency risk or within the insurance industry. This study helps shed light on these questions by examining the relation between derivative hedging and insurer insolvency risk.

Prior studies ${ }^{4,6}$ employ various measures entailing market value of the company to proxy firm risk. Because of the fact that most insurers in Taiwan are not listed firms, however, we cannot measure the effects of derivative use on market risk measures. Thus, the solvency ratio (solvency margin expressed as a percentage of premium income) is used in this research as an indicator of insurer insolvency risk. ${ }^{26}$

\section{Research design}

The sample

We obtain data on notional amount of derivative contracts and insurer characteristics, taken mostly from year books and annual financial reports provided by the Taiwan

\footnotetext{
${ }^{20}$ Yang et al. (2006).

${ }^{21}$ For example, Dadalt et al. (2002).

22 Bali et al. (2007).

${ }^{23}$ Venkatachalam (1996).

${ }^{24}$ Sinkey and Carter (2000).

25 Adkins et al. (2007).

${ }^{26}$ Daykin et al. (1994).
} 
Table 3 Number of life and non-life insurers

\begin{tabular}{lcccc}
\hline & \multicolumn{3}{c}{ Number of insurers } \\
\cline { 2 - 5 } & 2001 & 2002 & 2003 & Total number of firms \\
\hline Life insurers included in the sample & 27 & 27 & 27 & 81 \\
Life insurers in business & $(93 \%)$ & $(96 \%)$ & $(100 \%)$ & $(96 \%)$ \\
Non-life insurers included in the sample & 29 & 28 & 27 & 84 \\
& 23 & 24 & 24 & 71 \\
Non-life insurers in business & $(82 \%)$ & $(89 \%)$ & $(100 \%)$ & $(90 \%)$ \\
\hline
\end{tabular}

Note: The percentages in parentheses represent the ratio of number of insurers included in the sample to number of insurers in business.

Insurance Institute, a think tank on insurance in Taiwan. The data is verified and supplemented using company annual reports. Annual data for life and non-life insurers from 2001 to 2003 is collected. As shown in Table 3, 96 and 90 per cent of life and non-life insurers in business respectively are included in our sample. All large insurers in terms of total assets and gross premiums written also are included. Thus, our sample is representative of the whole insurance industry.

It is worth mentioning that insurers in Taiwan can only carry out derivative transactions for hedging purposes in accordance with "Guidance Note on Derivative Transactions by Insurers" issued by the Financial Supervisory Commission of Taiwan. According to these regulations, insurers must clearly disclose their derivative use and the risk exposures to be hedged in their financial statements, making possible this study on the relation between derivative hedging and solvency.

\section{Control variables}

As regards the control variables, we follow Guay ${ }^{6}$ and Hentschel and Kothari ${ }^{4}$ in using leverage (LEVER) and the book value of common equity (EBV). Leverage is introduced to account for the fact that an insurer's capital structure may be related to its solvency. Insurers with excessive leverage are relatively likely to become insolvent. ${ }^{27}$ We use a leverage variable defined as the ratio of liabilities to assets. The book value of common equity is introduced to account for the influence of cushion considerations.

A number of insurer characteristics also are included in the regressions to avoid omitted variables bias, since past research has suggested the importance these considerations. These variables include firm size (SIZE), degree of concentration of premiums (HERFP), interest rate risk exposure (MISAST and MISLIA), foreign exchange rate risk (FX), underwriting leverage (UNDLEVER), growth opportunity (GROWTH), reinsurance dependence (REINS), net interest margin (NIM), the sale of investment-linked insurance (INV) (life insurance only) and business mix. All these variables are considered in theory to be related to insurer solvency. The definitions of

\footnotetext{
${ }^{27}$ Shiu (2005).
} 
Table 4 Variables and their definitions

\begin{tabular}{|c|c|}
\hline Variable & Definition \\
\hline \multicolumn{2}{|l|}{ Dependent variable } \\
\hline SR & Ratio of solvency margin to premium income \\
\hline \multicolumn{2}{|l|}{ Independent variables } \\
\hline PAR & Participation decision: 1 for derivative users, 0 otherwise. \\
\hline EXT & $\begin{array}{l}\text { Extent decision: the balance of year-end notional value of } \\
\text { derivative instruments scaled by total assets }\end{array}$ \\
\hline LEVER & Ratio of liabilities to assets \\
\hline EBV & Book value of common equity \\
\hline SIZE & The natural logarithm of total admissible assets \\
\hline HERFP & $\begin{array}{l}\text { Herfindahl index of net premiums written. Suppose } X \text { consists of } M \\
\text { components where each component denotes } x_{k} \text { and } k=1,2,3, \ldots, M \text {. } \\
\text { The Herfindahl index is computed as } \sum_{k=1}^{M}\left(x_{k} / X\right)^{2} \text { to measure the } \\
\text { concentration of } X \text {. }\end{array}$ \\
\hline MISAST & $\begin{array}{l}\text { Mismatch where non-current assets outweigh non-current liabilities } \\
\text { scaled by book value }\end{array}$ \\
\hline MISLIA & $\begin{array}{l}\text { Mismatch where non-current liabilities outweigh non-current assets } \\
\text { scaled by book value }\end{array}$ \\
\hline FX & Total amount of foreign investment scaled by book value of firm \\
\hline UNDLEVER & Ratio of premiums written to surplus \\
\hline GROWTH & Cash reinvestment ratio multiplied by return on equity \\
\hline REINS & $\begin{array}{l}\text { Ratio of reinsurance ceded to the sum of direct premiums written } \\
\text { and reinsurance assumed }\end{array}$ \\
\hline NIM & Net interest margin \\
\hline INV & $\begin{array}{l}\text { Value of underlying assets represented by investment-linked } \\
\text { insurance deflated by gross written premiums [for life sector only] }\end{array}$ \\
\hline $\begin{array}{l}\text { Life business mix: life (LIFE), } \\
\text { accident (ACCI), health } \\
\text { (HEAL) and annuity (ANNU). }\end{array}$ & $\begin{array}{l}\text { The proportions of net earned premiums written in each of the four } \\
\text { lines of business, including life, accident, health and annuity [for } \\
\text { life sector only] }\end{array}$ \\
\hline Non-life business mix: fire & The proportions of net earned premiums written in each of the five \\
\hline $\begin{array}{l}\text { (FIRE), marine aviation \& } \\
\text { transport (MAT), motor }\end{array}$ & $\begin{array}{l}\text { lines of business, including fire, marine aviation and transport, } \\
\text { motor, liability and miscellaneous [for non-life sector only] }\end{array}$ \\
\hline
\end{tabular}

(MOTOR), liability (LIAB)

and miscellaneous (MIS)

control variables are described in Table 4 and their hypothesised relationship with solvency discussed below.

Firm size, proxied by the natural logarithm of total admissible assets, is included in the models to account for economies of scale. We calculate the Herfindahl index of net premiums written to reflect the concentration of product mix. Both interest rate and currency risks are included as control variables to account for the effects of these two major market risks on insurer solvency. Prior research ${ }^{27}$ argues that an insurer with excess underwriting leverage is relatively likely to become insolvent. Thus, we include underwriting leverage to account for its possible effects on solvency. A measure of the growth opportunity is included to control for changes in solvency unrelated to derivative usage. The rationale for this measure is that insurers with more growth opportunities are expected to perform better and thus have a relatively low likelihood 
of insolvency and a high level of solvency. Previous evidence ${ }^{28}$ suggests that the purchase of reinsurance can substitute for capital. Insurers with more reinsurance are less likely to become insolvent. We use reinsurance ceded over the sum of direct premiums and reinsurance assumed as a proxy. We also include net interest margin as one of the control variables because it may be related to solvency. For life insurers, we control for the sale of investment-linked insurance products since insurers selling such products are highly exposed to capital markets risk as well as return. We also include variables related to business mix as control variables.

\section{Methodology}

To assess the effect of derivative use on insurer solvency, we estimate the following model using panel estimation techniques:

$$
\text { Solvency }_{i, t}=f\left(\text { Derivative Use } e_{i, t}, C V_{i, t}\right)+v_{i}+\varepsilon_{i, t},
$$

where Solvency ${ }_{i t}$ is the solvency ratio of insurer $i$ at time $t$. Derivative Use ${ }_{i t}$ is a dummy variable (user $=1$; non-user $=0$ ) to represent the participation decision on derivative use or a continuous variable (proxied by the balance of year-end notional value of derivatives instruments scaled by total assets of the insurer) to represent the extent decision. $C V_{i t}$ refers to the set of control variables which are related to insurer solvency based on the literature reviewed. $v_{i}$ accounts for individual effects and $\varepsilon_{i, t}$ is an error term. Besides, since the regressions involve multiple years, we also include yearly dummies, which are not reported here.

We are aware of the likelihood that our analysis may suffer from the problem of endogeneity. Since the risk faced and the derivatives held by the firm may be simultaneously determined, endogeneity could be an econometric issue. If this is the case, the classical OLS assumption that explanatory variables are exogenous and uncorrelated with the error term would be violated. The coefficient estimates obtained from OLS regressions would then be biased and inconsistent. ${ }^{14}$ To test for endogeneity, a Hausman test with the null of no endogeneity is performed. Our results produce no evidence that insurer risk and derivative holdings are endogenously determined (results available on request). ${ }^{29}$

\footnotetext{
${ }^{28}$ For example, Garven and Lamm-Tennant (2003); Cole and McCullough (2006).

${ }^{29}$ The first step in conducting a Hausman test is to find appropriate instrumental variables which are uncorrelated with the error term (the first requirement) but associated with the proxy variables of derivative utilisation (the second requirement). There is no universally recognised approach to testing the validity of available instruments. A Pearson correlation test is utilised here. The possible candidates for instruments are the significant variables obtained from the literature on determinants of decision on derivative use. We employ a Pearson correlation test to investigate the relationships between derivative usage and the chosen variables, and between these variables and the error term. Those satisfying both requirements are selected as instrumental variables for the Hausman test. The results of the correlation and Hausman tests are available on request. In addition, any explanatory variables (other than the proxy for derivative use) that are not correlated with the error term are also included as instruments. This is to satisfy the order condition for identification, which requires that there are at least as many instruments as there are coefficients in the model. None of these variables are significantly related to the error term. The life insurance results indicate that derivative usage is not endogenously determined and accordingly it is
} 
The sample of insurers that use derivatives is not a random sample of insurers. Moreover, there are only 0,3 , and 6 non-life insurers using derivatives in the sample respectively in the years of our data, indicating a selection issue. If this is the case, this selectivity may bias the coefficients estimated. In order to address the issue on self-selection bias, we use the Heckman's ${ }^{30}$ two-step estimation method. Drawing on Shiu et al., ${ }^{31}$ we estimate a probit of the treatment on several factors that are related to Taiwanese insurers' decision to use derivatives. The treatment is a binary indicator variable that takes on the value of 1 , if the insurer uses derivatives, and 0 , if the insurer does not use derivatives. We then run an OLS regression for Eq. (1), using the inverse Mills ratio (obtained from the probit regression) as an additional regressor.

\section{Empirical results}

The means of the solvency ratios for the life derivative users and non-users are 0.2096 and 0.2133 , while those for the non-life derivative users and non-users are 0.6008 and 0.7626 , respectively. Using an independent-samples two-tailed $t$-test, we examine whether there is any statistical difference in the means of solvency ratios between users and non-users. The $t$-statistics [ $p$-values] for the life and non-life sectors are -0.0890 [0.9293] and -0.7928 [0.4368] respectively, suggesting that the null hypotheses that the means of the solvency ratios of derivative users are equal to those of the non-users cannot be rejected at the 0.05 level.

We then examine whether firm solvency is affected by derivative activities measured by the participation decision and the participation extent. Other firm characteristics significantly influencing solvency are also reported below. The life and non-life results are provided in Tables 5 and 6 respectively.

As stated previously, we use the Heckman ${ }^{30}$ two-step estimation procedure to address the possible problem of self-selection bias. We first estimate a probit model for the participation decision on derivative use to obtain the inverse Mills ratio. We then use this ratio as an additional regressor to estimate an OLS model. We also estimate OLS, and one-factor random-effects (RE) regression models without using the inverse Mills ratio as one of the regressors. $F$ - tests for the overall statistical goodness-of-fit of the empirical models are all significant at the 0.001 level, confirming that the fitted models are better than a null model without explanatory variables. The adjusted $R^{2}$ values range from 0.8210 to 0.8841 .

In this paper, we use solvency ratio measured by the ratio of solvency margin to premium income to evaluate whether the financial health of insurers is affected by off-balance-sheet activities. In one sense, a firm with higher solvency ratio is regarded

not necessary to employ the instrumental variable estimation, such as the two-stage least squares approach, in the analysis. However, for the non-life sector, there is no qualified instrumental variable. As suggested by Maddala (2001), it is difficult in practice to find appropriate instruments. The results obtained from the instrumental variable estimation, if a poor instrument is used, are worse than those from the OLS specification.

${ }^{30}$ Heckman (1979).

${ }^{31}$ Shiu et al. (2008). 
as one with lower insolvency risk. For robustness checks, we also use the ratio of book value of equity to gross premiums written and the ratio of book value of equity to net premiums written. The tenor of the results is quantitatively unchanged.

\section{Effects of the decision to use derivatives}

The proxy for insurer solvency is regressed on the participation decision (assigned 1 if there is a year-end derivatives position) and several firm characteristics. The life results in Table 5 show that the participation variable (PAR) generally is not significantly related to solvency ( $p$-value $>0.1$ ), except in Model 1 estimated using the

Table 5 Effects of derivative use on solvency for life insurance sector

\begin{tabular}{|c|c|c|c|c|c|}
\hline Variable & Model 1: HTSR & Model 2: OLS & Model 3: RE & Model 4: OLS & Model 5: RE \\
\hline Constant & $\begin{array}{l}1.4084^{* * * *} \\
(5.552)\end{array}$ & $\begin{array}{l}1.5906^{* * *} \\
(6.907)\end{array}$ & $\begin{array}{l}1.4758^{* * * *} \\
(6.205)\end{array}$ & $\begin{array}{l}1.6509^{* * *} \\
(7.526)\end{array}$ & $\begin{array}{l}1.4848^{* * * *} \\
(6.480)\end{array}$ \\
\hline PAR & $\begin{array}{l}-0.0849^{*} \\
(-1.894)\end{array}$ & $\begin{array}{l}-0.0267 \\
(-0.989)\end{array}$ & $\begin{array}{l}-0.0029 \\
(-0.132)\end{array}$ & & \\
\hline EXT & & & & $\begin{array}{c}0.1090 \\
(1.000)\end{array}$ & $\begin{array}{c}-0.5310 \\
(-0.006)\end{array}$ \\
\hline LEVER & $\begin{array}{l}-2.0917^{* * *} \\
(-10.048)\end{array}$ & $\begin{array}{l}-2.0902^{* * * *} \\
(-9.903)\end{array}$ & $\begin{array}{l}-1.9878^{* * *} \\
(-10.034)\end{array}$ & $\begin{array}{l}-2.1058^{* * *} \\
(-10.024)\end{array}$ & $\begin{array}{l}-1.9886^{* * *} \\
(-10.027)\end{array}$ \\
\hline EBV & $\begin{array}{c}-0.0009 \\
(-1.207)\end{array}$ & $\begin{array}{c}-0.0006 \\
(-0.816)\end{array}$ & $\begin{array}{c}-0.0006 \\
(-0.665)\end{array}$ & $\begin{array}{c}-0.0005 \\
(-0.715)\end{array}$ & $\begin{array}{c}-0.0006 \\
(-0.651)\end{array}$ \\
\hline SIZE & $\begin{array}{l}0.0393^{* * *} \\
(3.437)\end{array}$ & $\begin{array}{l}0.0282^{* * *} \\
(3.044)\end{array}$ & $\begin{array}{l}0.0251 * * \\
(2.301)\end{array}$ & $\begin{array}{l}0.0220 * * * \\
(2.867)\end{array}$ & $\begin{array}{l}0.0245^{* *} \\
(2.486)\end{array}$ \\
\hline HERFP & $\begin{array}{l}-0.1522 \\
(-1.098)\end{array}$ & $\begin{array}{l}-0.2052 \\
(-1.502)\end{array}$ & $\begin{array}{l}-0.2377^{*} \\
(-1.846)\end{array}$ & $\begin{array}{l}-0.2236^{*} \\
(-1.673)\end{array}$ & $\begin{array}{l}-0.2404^{*} \\
(-1.893)\end{array}$ \\
\hline MISAST & $\begin{array}{l}-0.0063 \\
(-1.515)\end{array}$ & $\begin{array}{l}-0.0061 \\
(-1.426)\end{array}$ & $\begin{array}{l}-0.0055^{*} \\
(-1.656)\end{array}$ & $\begin{array}{l}-0.0064 \\
(-1.513)\end{array}$ & $\begin{array}{l}-0.0055^{*} \\
(-1.662)\end{array}$ \\
\hline MISLIA & $\begin{array}{r}0.0002 \\
(0.387)\end{array}$ & $\begin{array}{c}0.0006 \\
(1.167)\end{array}$ & $\begin{array}{c}0.0007 \\
(1.329)\end{array}$ & $\begin{array}{r}0.0007 \\
(1.299)\end{array}$ & $\begin{array}{c}0.0008 \\
(1.358)\end{array}$ \\
\hline FX & $\begin{array}{r}0.1421 \\
(1.019)\end{array}$ & $\begin{array}{c}0.0512 \\
(0.396)\end{array}$ & $\begin{array}{c}0.0720 \\
(0.640)\end{array}$ & $\begin{array}{l}-0.0640 \\
(-0.475)\end{array}$ & $\begin{array}{c}0.0662 \\
(0.552)\end{array}$ \\
\hline UNDLEVER & $\begin{array}{l}-0.0035^{*} \\
(-1.809)\end{array}$ & $\begin{array}{l}-0.0029 \\
(-1.485)\end{array}$ & $\begin{array}{l}-0.0022 \\
(-1.259)\end{array}$ & $\begin{array}{l}-0.0023 \\
(-1.202)\end{array}$ & $\begin{array}{l}-0.0022 \\
(-1.237)\end{array}$ \\
\hline GROWTH & $\begin{array}{l}-0.0010^{*} \\
(-1.831)\end{array}$ & $\begin{array}{c}-0.0007 \\
(-1.284)\end{array}$ & $\begin{array}{l}-0.0007 \\
(-1.380)\end{array}$ & $\begin{array}{l}-0.0005 \\
(-0.956)\end{array}$ & $\begin{array}{l}-0.0006 \\
(-1.369)\end{array}$ \\
\hline REINS & $\begin{array}{l}-0.0015 \\
(-0.868)\end{array}$ & $\begin{array}{l}-0.0013 \\
(-0.753)\end{array}$ & $\begin{array}{l}-0.0021 \\
(-1.200)\end{array}$ & $\begin{array}{l}-0.0013 \\
(-0.766)\end{array}$ & $\begin{array}{c}-0.0021 \\
(-1.195)\end{array}$ \\
\hline NIM & $\begin{array}{l}6.1029^{* * * *} \\
(5.489)\end{array}$ & $\begin{array}{l}5.8817^{* * * *} \\
(5.257)\end{array}$ & $\begin{array}{l}5.8435^{* * * *} \\
(5.385)\end{array}$ & $\begin{array}{l}6.0394^{* * * *} \\
(5.353)\end{array}$ & $\begin{array}{l}5.8529 * * * \\
(5.384)\end{array}$ \\
\hline INV & $\begin{array}{l}0.0026^{* * * *} \\
(11.117)\end{array}$ & $\begin{array}{l}0.0024^{* * * *} \\
(11.145)\end{array}$ & $\begin{array}{l}0.0024^{* * * *} \\
(12.892)\end{array}$ & $\begin{array}{l}0.0024 * * * \\
(11.129)\end{array}$ & $\begin{array}{l}0.0024 * * * \\
(13.034)\end{array}$ \\
\hline LIFE & $\begin{array}{c}0.1053 \\
(0.624)\end{array}$ & $\begin{array}{c}0.1332 \\
(0.784)\end{array}$ & $\begin{array}{c}0.2241 \\
(1.386)\end{array}$ & $\begin{array}{c}0.2036 \\
(1.274)\end{array}$ & $\begin{array}{c}0.2279 \\
(1.425)\end{array}$ \\
\hline ACCI & $\begin{array}{l}-0.1234 \\
(-0.811)\end{array}$ & $\begin{array}{l}-0.1369 \\
(-0.888)\end{array}$ & $\begin{array}{c}0.0154 \\
(0.100)\end{array}$ & $\begin{array}{l}-0.0976 \\
(-0.645)\end{array}$ & $\begin{array}{c}0.0163 \\
(0.107)\end{array}$ \\
\hline HEAL & $\begin{array}{l}-0.4784 * * * \\
(-3.228)\end{array}$ & $\begin{array}{l}-0.5015^{* * * *} \\
(-3.353)\end{array}$ & $\begin{array}{l}-0.5361^{* * *} \\
(-3.270)\end{array}$ & $\begin{array}{l}-0.4846^{* * * *} \\
(-3.236)\end{array}$ & $\begin{array}{l}-0.5369 * * * \\
(-3.275)\end{array}$ \\
\hline
\end{tabular}


Table 5 (continued)

\begin{tabular}{|c|c|c|c|c|c|}
\hline Variable & Model 1: HTSR & Model 2: OLS & Model 3: RE & Model 4: OLS & Model 5: RE \\
\hline IMR & $\begin{array}{r}0.0647 \\
(1.613)\end{array}$ & & & & \\
\hline$R^{2}$ & 0.8664 & 0.8602 & & 0.8603 & \\
\hline Adjusted $R^{2}$ & 0.8259 & 0.8210 & & 0.8210 & \\
\hline$F$ test & $\begin{array}{c}21.37 * * * \\
{[0.0000]}\end{array}$ & $\begin{array}{c}21.92 * * * \\
{[0.0000]}\end{array}$ & & $\begin{array}{c}21.93 * * * \\
{[0.0000]}\end{array}$ & \\
\hline
\end{tabular}

Note: The dependent variable for the five specifications above is insurer solvency, proxied by the ratio of solvency margin to premium income. The Heckman two-stage regression (HTSR), ordinary least squares (OLS) regression and random-effects regression models are estimated. The numbers in the parentheses and brackets are $t$-statistics and $p$-values, respectively. PAR $=1$ for derivatives users, 0 otherwise; EXT = the balance of year-end notional value of derivatives instruments scaled by total assets; LEVER = ratio of liabilities to assets; $\mathrm{EBV}=$ book value of common equity; $\mathrm{SIZE}=$ the natural logarithm of total admissible assets; HERFP $=$ Herfindahl index of net premiums written; MISAST = mismatch where non-current assets outweigh non-current liabilities scaled by book value; MISLIA = mismatch where non-current liabilities outweigh non-current assets scaled by book value; $\mathrm{FX}=$ total amount of foreign investment scaled by book value; UNDLEVER = ratio of premiums written to surplus; GROWTH = cash reinvestment ratio multiplied by return on equity; REINS = ratio of reinsurance ceded to the sum of direct premiums written and reinsurance assumed; NIM = net interest margin; INV = value of underlying assets represented by investment-linked insurance deflated by gross written premiums; LIFE = ratio of net earned premiums written in life business to all net earned premiums written; ACCI = ratio of net earned premiums written in accident business to all net earned premiums written; HEAL = ratio of net earned premiums written in health business to all net earned premiums written; IMR = the inverse Mills ratio obtained from the unreported probit results. * Significant at the 10 per cent level; ** Significant at the 5 per cent level; *** Significant at the 1 per cent level.

Table 6 Effects of derivative use on solvency for non-life insurance sector

\begin{tabular}{lccccc}
\hline Variable & Model 6: HTSR & Model 7: OLS & Model 8: RE & Model 9: OLS & Model 10: RE \\
\hline Constant & 1.0540 & 0.6651 & 1.5485 & 1.0606 & 1.6801 \\
& $(0.764)$ & $(0.465)$ & $(1.112)$ & $(0.755)$ & $(1.231)$ \\
PAR & $-1.4654^{* * *}$ & -0.2715 & $-0.2390^{* *}$ & & \\
& $(-2.770)$ & $(-1.622)$ & $(-2.022)$ & & $-3.198^{* *}$ \\
EXT & & & & $-4.2653^{* *}$ & $(-2.375)$ \\
& & & & $(-2.432)$ & $-1.7224^{* *}$ \\
LEVER & -1.3811 & $-1.6699^{*}$ & $-1.6709^{* *}$ & $-1.5888^{*}$ & $(-2.424)$ \\
EBV & $(-1.673)$ & $(-1.958)$ & $(-2.303)$ & $(-1.917)$ & $0.0237^{*}$ \\
& $0.0324^{* *}$ & 0.0200 & $0.0257^{*}$ & 0.0183 & $(1.700)$ \\
SIZE & $(2.538)$ & $(1.642)$ & $(1.802)$ & $(1.569)$ & -0.0380 \\
& -0.0040 & 0.0242 & -0.0276 & -0.0033 & $(-0.377)$ \\
HERFP & $(-0.044)$ & $(0.255)$ & $(-0.268)$ & $(-0.035)$ & 0.5012 \\
& 0.7535 & 0.7431 & 0.4009 & 0.7734 & $(1.062)$ \\
MISAST & $(1.408)$ & $(1.330)$ & $(0.825)$ & $(1.433)$ & $0.0040^{*}$ \\
MISLIA & 0.0044 & 0.0036 & $0.0043^{*}$ & 0.0034 & $(1.774)$ \\
FX & $(1.507)$ & $(1.184)$ & $(1.867)$ & $(1.134)$ & -0.0048 \\
& 0.0036 & 0.0017 & -0.0040 & 0.0003 & $(-1.626)$
\end{tabular}


Table 6 (continued)

\begin{tabular}{|c|c|c|c|c|c|}
\hline Variable & Model 6: HTSR & Model 7: OLS & Model 8: RE & Model 9: OLS & Model 10: RE \\
\hline \multirow[t]{2}{*}{ UNDLEVER } & -0.0467 & -0.0314 & $-0.0593^{*}$ & -0.0397 & -0.0514 \\
\hline & $(-1.289)$ & $(-0.843)$ & $(-1.700)$ & $(-1.090)$ & $(-1.510)$ \\
\hline \multirow[t]{2}{*}{ GROWTH } & $-0.0197^{*}$ & -0.0111 & 0.0026 & -0.0126 & -0.0006 \\
\hline & $(-1.833)$ & $(-1.050)$ & $(0.311)$ & $(-1.225)$ & $(-0.072)$ \\
\hline \multirow[t]{2}{*}{ REINS } & $0.0056^{*}$ & $0.0078 * *$ & $0.0084 * * *$ & $0.0062 *$ & $0.0075^{* * *}$ \\
\hline & $(1.781)$ & $(2.484)$ & $(3.045)$ & $(1.948)$ & $(2.697)$ \\
\hline \multirow[t]{2}{*}{ NIM } & 1.3713 & $10.5566^{* * *}$ & $14.557 * * *$ & $7.3301^{*}$ & $11.6591 * * *$ \\
\hline & $(0.264)$ & $(2.925)$ & $(5.520)$ & $(1.884)$ & $(3.833)$ \\
\hline \multirow[t]{2}{*}{ FIRE } & 0.1122 & -0.1555 & $-1.2054 * * *$ & 0.0016 & $-0.9802 * *$ \\
\hline & $(0.219)$ & $(-0.299)$ & $(-2.849)$ & $(0.003)$ & $(-2.340)$ \\
\hline \multirow[t]{2}{*}{ MAT } & 0.5314 & 0.8143 & 1.0403 & 0.7558 & 0.9415 \\
\hline & $(0.681)$ & $(1.012)$ & $(1.026)$ & $(0.969)$ & $(0.955)$ \\
\hline \multirow[t]{2}{*}{ MOTOR } & -0.4475 & -0.6110 & 0.0257 & -0.4298 & 0.1254 \\
\hline & $(-1.009)$ & $(-1.336)$ & $(0.049)$ & $(-0.967)$ & $(0.248)$ \\
\hline \multirow[t]{2}{*}{ LIAB } & 0.5980 & 0.5019 & $1.1000^{* *}$ & 0.6635 & $1.2690 * *$ \\
\hline & $(1.153)$ & $(0.929)$ & $(2.066)$ & $(1.277)$ & $(2.426)$ \\
\hline \multirow[t]{2}{*}{ IMR } & $0.6835^{* *}$ & & & & \\
\hline & $(2.368)$ & & & & \\
\hline$R^{2}$ & 0.9135 & 0.9037 & & 0.9093 & \\
\hline Adjusted $R^{2}$ & 0.8841 & 0.8736 & & 0.8809 & \\
\hline \multirow[t]{2}{*}{$F$ test } & $31.06 * * *$ & $29.94 * * *$ & & $31.97 * * *$ & \\
\hline & {$[0.0000]$} & {$[0.0000]$} & & {$[0.0000]$} & \\
\hline
\end{tabular}

Note: The dependent variable for the five specifications above is insurer solvency, proxied by the ratio of solvency margin to premium income. The Heckman two-stage regression (HTSR), ordinary least squares (OLS) regression, and random-effects regression models are estimated. The numbers in the parentheses and brackets are $t$-statistics and $p$-values, respectively. PAR $=1$ for derivatives users, 0 otherwise; EXT = the balance of year-end notional value of derivatives instruments scaled by total assets; $\mathrm{LEVER}=$ ratio of liabilities to assets; $\mathrm{EBV}=$ book value of common equity; SIZE = the natural logarithm of total admissible assets; HERFP $=$ Herfindahl index of net premiums written;

MISAST $=$ mismatch where non-current assets outweigh non-current liabilities scaled by book value; MISLIA = mismatch where non-current liabilities outweigh non-current assets scaled by book value; $\mathrm{FX}=$ total amount of foreign investment scaled by book value; UNDLEVER = ratio of premiums written to surplus; GROWTH = cash reinvestment ratio multiplied by return on equity; REINS = ratio of reinsurance ceded to the sum of direct premiums written and reinsurance assumed; NIM = net interest margin; FIRE $=$ ratio of net earned premiums written in fire business to all net earned premiums written; $\mathrm{MAT}=$ ratio of net earned premiums written in marine aviation and transport business to all net earned premiums written; MOTOR = ratio of net earned premiums written in motor business to all net earned premiums written; $\mathrm{LIAB}=$ ratio of net earned premiums written in liability business to all net earned premiums written; IMR $=$ the inverse Mills ratio obtained from the unreported probit results. * Significant at the 10 per cent level; ** Significant at the 5 per cent level; *** Significant at the 1 per cent level.

Heckman two-stage estimation procedure. It is worth noting that, however, the inverse Mills ratio is not found to be significant in this model $(t$-statistic $=1.343, p$-value $>0.1)$, suggesting that problems associated with selectivity bias are relatively unlikely in the model. Colquitt and Hoyt ${ }^{17}$ also find the inverse Mills ratio obtained from the probit model is statistically insignificant and suggest estimating models using OLS. 
Moreover, the two-step method may be very inefficient. ${ }^{32}$ Furthermore, the Lagrange Multiplier (LM) test results favour OLS over RE models ( $L M$ test statistic $=1.17$, $p$-value $=0.2789)$. Taken together, Model $2($ OLS $)$ seems to be more appropriate than Models 1 (Heckman two-stage regression) and 3 (RE regression), suggesting that life insurers' decision to participate in derivative activities is not important in interpreting the variation of solvency.

As presented in Table 6, conversely, the inverse Mills ratio is significant in Model 6 (Heckman two-stage regression), suggesting the presence of selectivity bias in the non-life data. This justifies the use of the Heckman two-stage procedure rather than OLS/ RE regressions. The Heckman two-stage regression results show that non-life insurers' decision to participate in derivative activities is negatively related to their solvency $(t$-statistic $=-2.770, p$-value $<0.01)$.

\section{Effects of the extent of derivative usage}

Tables 5 and 6 also present the results concerning the influence of the participation extent of derivative use on insurer solvency. The solvency is regressed on the level of derivative use measured by year-end notional value of the derivatives position and other firm characteristics. As shown in Models 4 and 5, derivative holdings in the life sector have insignificant association with insurer solvency ( $p$-value $>0.1)$. The lack of association between derivative activities and solvency is consistent with the findings of Hentschel and Kothari ${ }^{4}$ that derivative holdings of firms have no influence on their return volatility.

It is noted, however, in Models 9 and 10 that a negative and significant relationship between derivative utilisation and solvency ratio exists in non-life insurance ( $p$-value $<$ $0.05)$, indicating that non-life insurers actively participating in derivative transactions could suffer from a higher likelihood of insolvency. This finding is consistent with the previous result that non-life hedgers have lower solvency than non-hedgers. One of the possible explanations is that if a non-life insurer uses derivatives for hedging purposes, it can operate at a lower solvency margin. In one sense, this type of explanation is consistent with Leland ${ }^{33}$ argument that hedging allows firms to take on more debt.

\section{Conclusion}

Mounting evidence on the benefits of derivative use highlights the need for financial firms as well as non-financial firms to use derivatives to shift risks. Most prior studies on derivative use, for example, Cummins et al., ${ }^{10}$ Sinkey and Carter, ${ }^{24}$ and Cummins et al. ${ }^{19}$ focus on its determinants. Few studies, such as Guay, ${ }^{6}$ Hentschel and Kothari, ${ }^{4}$ and Yang et al., ${ }^{20}$ examine the relationship between the use of derivatives and firm risk. To our knowledge, there is no research investigating the impact of derivative usage on firm insolvency risk/solvency in the context of insurance. In this paper, we provide an empirical analysis on derivative use for hedging purposes and

\footnotetext{
32 Johnston and DiNardo (1997).

${ }^{33}$ Leland (1998).
} 
solvency of insurers in Taiwan. Our data on derivative hedging allows us to examine this issue.

This paper investigates the differences in solvency across life and non-life insurers. Using three years of data, we examine whether the differences in solvency across insurers can be systematically explained by derivative participation/extent, while controlling a number of insurer characteristics. We pay particular attention to separate the effect of derivative participation on solvency from that of derivative extent. Our results allow us to draw the following main conclusion. Derivative holdings of life insurers generally have no significant relationship with solvency. Nevertheless, it is worth noting that a negative and significant relationship between derivatives utilisation and solvency ratio is documented in the non-life insurance sector. Since the most common derivative activities for Taiwanese insurers, especially non-life firms, are in foreign currency forward contracts, our findings may be generalised to other insurance markets that heavily engage in such contracts. It is also worth noting that the specific reporting requirement and traits of the insurance market in Taiwan may impact the results. For instance, the use of end-of-year derivative holdings may lead to underestimating the true extent to which an insurer engages in derivative activities. The underestimate may also result from the fact that some insurers that use financial instruments with derivative characteristics are not classified as derivative users.

We consider that our research findings have important implications for the regulator. Derivative hedging was originally aimed at increasing insurer solvency. The empirical absence of higher level of solvency following derivative hedging suggests that this aim apparently is not achieved.

\section{About the Author}

Yung-Ming Shiu is Associate Professor in the Department of Business Administration at National Cheng Kung University, Taiwan. He teaches risk management and insurance. His research focuses on the areas of derivatives, corporate hedging, risk management and insurance. His research has appeared in a number of scholarly and trade journals such as the Journal of Derivatives, the Journal of Futures Markets, the Annals of Actuarial Science and the British Actuarial Journal.

\section{References}

Allayannis, G. and Ofek, E. (2001) 'Exchange rate exposure, hedging and the use of foreign currency derivatives', Journal of International Money and Finance 20: 273-296.

Allayannis, G. and Weston, J.P. (2001) 'The use of foreign currency derivatives and firm market value', The Review of Financial Studies 14: 243-276.

Adkins, L.C., Carter, D.A. and Simpson, W.G. (2007) 'Managerial incentives and the use of foreignexchange derivatives by banks', The Journal of Financial Research 30: 399-413.

Bali, T.G., Hume, S.R. and Martell, T.F. (2007) 'A new look at hedging with derivatives: Will firms reduce market risk exposure?' The Journal of Futures Markets 27(11): 1053-1083.

Carter, D.A., Rogers, D.A. and Simkins, B.J. (2006) 'Does hedging affect firm value? Evidence from the US airline industry', Financial Management 35(1): 53-86.

Cole, C.R. and McCullough, K.A. (2006) 'A reexamination of the corporate demand for reinsurance', Journal of Risk and Insurance 73(1): 169-192. 
Colquitt, L.L. and Hoyt, R.E. (1997) 'Determinants of corporate hedging behavior: Evidence from the life insurance industry', Journal of Risk and Insurance 64(4): 649-671.

Cummins, J.D., Phillips, R.D. and Smith, S.D. (1997) 'Corporate hedging in the insurance industry: The use of financial derivatives by U.S. insurers', The North American Actuarial Journal 1(1): 13-49.

Cummins, J.D., Phillips, R.D. and Smith, S.D. (2001) 'Derivatives and corporate risk management: Participation and volume decisions in the insurance industry', Journal of Risk and Insurance 68(1): 51-92.

DaDalt, P., Gay, G.D. and Nam, J. (2002) 'Asymmetric information and corporate derivatives use', The Journal of Futures Markets 22: 241-267.

Daykin, C.D., Pentikäinen, T. and Pesonen, M. (1994) Practical Risk Theory for Actuaries, 1st edn, London: Chapman \& Hall.

Financial Services Authority (2008) 'The Prudential Sourcebook for Insurers', from http://www.fsahand book.info/FSA/html/handbook/INSPRU.

Froot, K.A., Scharfstein, D.S. and Stein, J.C. (1993) 'Risk management: Coordinating corporate investment and financing policies', Journal of Finance 48(5): 1629-1658.

Garven, J.R. and Lamm-Tennant, J. (2003) 'The demand for reinsurance: Theory and empirical tests', Insurance and Risk Management 71: 217-238.

Guay, W. (1999) 'The impact of derivatives on firm risk: An empirical examination of new derivative users', Journal of Accounting and Economics 26: 319-351.

Hardwick, P. and Adams, M. (1999) 'The determinants of financial derivatives use in the United Kingdom life insurance industry', Abacus 35(2): 163-184.

Heckman, J.J. (1979) 'Sample selection bias as a specification error', Econometrica 47: 153-161.

Hentschel, L. and Kothari, S.P. (2001) 'Are corporations reducing or taking risks with derivatives?' Journal of Financial and Quantitative Analysis 36: 93-118.

Jin, Y. and Jorion, P. (2006) 'Firm value and hedging: Evidence from U.S. oil and gas producers', Journal of Finance 61: 893-919.

Johnston, J. and DiNardo, J. (1997) Econometric Methods, 4th edn, Singapore: McGraw-Hill.

Koski, J.L. and Pontiff, J. (1999) 'How are derivatives used? Evidence from the mutual fund industry', Journal of Finance 54: 791-816.

Kupiec, P. and Nickerson, D. (2005) 'Insurers are not banks: Assessing liquidity, efficiency and solvency risk under alternative approaches to capital adequacy', The Geneva Papers on Risk and Insurance-Issues and Practice 30(4): 498-521.

Leland, H. (1998) 'Agency costs, risk management and capital structure', Journal of Finance 53(4): 1213-1243.

Maddala, G.S. (2001) Introduction to Econometrics, 3rd edn, Chichester: John Wiley \& Sons.

Nance, D.R., Smith Jr., C.W. and Smithson, C.W. (1993) 'On the determinants of corporate hedging', Journal of Finance 48: 267-284.

Shiu, Y. (2005) 'The determinants of solvency in the United Kingdom life insurance market', Applied Economics Letters 12: 339-344.

Shiu, Y., Adams, A. and Shin, Y. (2008) On the determinants of derivative hedging by insurance companies: Evidence from Taiwan, Working paper.

Sinkey, J.F. and Carter, D.A. (2000) 'Evidence on the financial characteristics of banks that do and do not use derivatives', The Quarterly Review of Economics and Finance 40: 431-449.

Smith Jr., C.W. and Stulz, R.M. (1985) 'The determinants of firms' hedging policies', Journal of Financial and Quantitative Analysis 20: 391-405.

Tufano, P. (1996) 'Who manages risk? An empirical examination of risk management practices in the gold mining industry', Journal of Finance 51(4): 1097-1137.

Venkatachalam, M. (1996) 'Value-relevance of banks' derivatives disclosures', Journal of Accounting and Economics 22: 327-355.

$\mathrm{Wu}$, D. (1973) 'Alternative tests of independence between stochastic regressors and disturbances', Econometrica 41: 733-750.

Yang, D., Song, I., Yi, J. and Yoon, Y. (2006) 'Effects of derivatives on bank risk', Review of Pacific Basin Financial Markets and Policies 9: 275-295. 